\title{
EL JUDAÍSMO Y LOS SABERES MEDIEVALES: ARTE Y CIENCIA PARA LA EUROPA MODERNA
}

\author{
Miguel Ángel Espinosa Villegas \\ Universidad de Granada
}

\section{RESUMEN}

El judaísmo medieval mantuvo una relación con el conocimiento y la ciencia que no puede comprenderse sin una revisión e identificación de sus particularidades. El vínculo entre lo moral y lo físico nacido entre los textos bíblicos justifica hasta nuestros días la necesidad de ahondar en la comprensión de lo real desde el ser humano y sus muchas facultades. La ciencia judía medieval no va a remolque de ninguna otra, aporta y participa activamente como difusora y creadora, tiene incluso sus propios mitos. La práctica de lo que hoy llamamos arte se adhiere también a ese corpus de sabiduría en el ámbito judío, como es el caso del libro, que difunde y materializa esos saberes.

Palabras Clave: judaísmo, ciencia, teoría, Sefarad, Edad Media.

\section{JUDAISM AND MEDIEVAL LORE: ART AND SCIENCE BOUND FOR A MODERN EUROPE}

\section{Abstract}

Medieval Judaism maintained a relationship with knowledge and science that cannot be understood without a revision and identification of its particularities. The link between the moral and the physical dimensions, as born in biblical texts, justifies until today the need to deepen the understanding of the real, always from the human being itself and its many faculties. Medieval Jewish science does not lag behind any other, but contributes and actively participates in the creation and diffusion processes. It even has its own myths. The practice of what we now call art also adheres to this corpus of wisdom in Judaism, as is the case of the book, which disseminates and materializes this knowledge.

Keywords: Judaism, science, theory, Sefarad, Middle Ages. 


\section{INTRODUCCIÓN: CONCEPTO Y MÉTODO DE CIENCIA EN EL JUDAÍSMO}

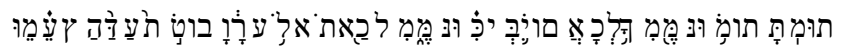

... mas del árbol de la ciencia del bien y del mal no comerás, porque el día que comieres de él, morirás sin remedio (Gn 2, 17)

Las siguientes reflexiones y precisiones tienen como objeto desterrar algunos de los mitos sobre el judaísmo y su relación con la ciencia que fueron surgiendo en la dialéctica establecida con las otras religiones monoteístas. Se acusa al judaísmo de no poseer un modo científico propio y caminar en la estela de la ciencia de cristianos y musulmanes sin aportar nada original. No obstante, como veremos, son varias las especificidades del comportamiento científico hebreo, desde su impronta moral a la configuración de un método analítico y empírico bastante temprano. Lejos de seguir la senda trazada por aquellas otras culturas con que convive, el judaísmo aporta siempre su manera peculiar de enfocar los temas y de tratarlos.

En esta relación entre la realidad y la adquisición de su conocimiento, el arte se presenta no solo como un instrumento de anotación y fijación de los logros obtenidos, sino también como una ventajosa herramienta de investigación, resultando prácticamente imposible sustraer la práctica artística de los laboratorios y talleres de ciencia medievales y modernos. Sin duda, esta peculiar sintonía es la base de la buena concordancia que el judaísmo establece con la modernidad cientificista a través de sus artistas, vilipendiados por propios y rechazados por extraños, pese a su valía vanguardista.

El Israel bíblico y las culturas antiguas carecían de un término específico para expresar el concepto de ciencia. Conocimiento, ley, idea o sabiduría son las palabras que sustituyen en los textos antiguos al concepto actual. Cada una de ellas ofrece un matiz de significado diferente, pero todas apuntan hacia la comprensión de un conjunto de saberes perfectamente estructurados acerca de la realidad, que es lo que hoy entendemos como tal.

Habitualmente, el análisis de las ciencias en el mundo judío parte del segundo capítulo del Génesis y su referencia al árbol situado por el propio Dios en medio del paraíso (Gn 2, 9). Estos estudios suelen olvidar que la expresión bíblica árbol de la ciencia no alude a cualquier tipo de conocimiento, sino específicamente a la ciencia del bien y del mal. No se presta atención tampoco a la palabra en estado constructo, de'at-ì עy- «concepto»o «idea», que se traduce por ciencia, aunque su significado es bastante más preciso. El árbol de la ciencia del bien y del mal es en realidad el árbol de la noción del bien y del mal. De esta manera, la capacidad de conocimiento acaba vinculada a la de discernimiento entre dos conceptos de tipo moral. El sistema científico de conocimiento de lo real emanado de la Biblia, al menos en su interpretación posterior cristiana, queda referido así a una formulación moral en el ámbito de lo religioso, al tiempo que se eleva al rango de peligroso don divino.

El ser humano decidirá en el ejercicio de su albedrío si vive al margen de ese conocimiento o muere al adquirirlo banalmente. Puede optar por equipararse a 
Dios, robando y alcanzando mágicamente ese conocimiento que Él pone a su alcance con solo comer del árbol, aun a sabiendas de que tal acto le excluye del paraíso de la inconsciencia: un ser humano prometeico al modo griego. Mas puede también comprender el sentido que la tradición ha querido hacer de este episodio otorgando al conocimiento la causa del sufrimiento humano.

La interpretación rabínica real dista mucho sin embargo de esta consideración. El judaísmo no concibe al ser humano del Edén como una entidad privada de conocimiento ${ }^{1}$ y dispuesta a robarlo por su necedad, pues su condición de creatura a imagen divina le hace racional e inteligente por definición. De este modo, la distorsión que introduce el fruto prohibido es, como muy bien parece entender Maimónides, según Rosenberg ${ }^{2}$, la imaginación, una facultad que consigue alejar la inteligencia humana de la realidad y la conduce al desvarío. Esta religión no condena la ciencia en ningún momento, pues la entiende como conocimiento efectivo de la propia realidad; tan solo proscribe todo aquello que conduzca a su falseamiento.

Desde el momento de la caída del ser humano, la razón entabla una batalla dialéctica con la imaginación y se erige en la única arma capaz de reparar mínimamente el error de haber adquirido una fortaleza engañosa. El conocimiento razonado, lejos de ser temido por la tradición judía, es el único recurso que Dios concede a su criatura para resarcir el daño y castigo que se inflige por propia mano en un acto de libre desobediencia. Se trata, no obstante, de un Dios que no exige más satisfacción que el aprendizaje positivo de las consecuencias derivadas. Como expiación de la falta cometida, el ser humano habrá de reconstruir la realidad inicial batallando contra la amenaza de deformación ilusoria y para tal empeño solo cuenta con la propia realidad creada como fuente de información, de la que él mismo es una parte esencial, y su raciocinio. El Antiguo Testamento nos presenta un sistema de relaciones a tres bandas donde el ser humano debe, tras un pacto con su Dios, alcanzar el conocimiento de la realidad y tomar conciencia de sí mismo como una parte más de la misma.

Definir posiciones y realidades es, sin duda, la principal tarea de la ciencia y el judaísmo podría haber acometido ese reto como lo hizo la cultura griega, esto es, dedicando su primer esfuerzo a la comprensión de la naturaleza envolvente que servía de escenario al ser humano y su acción. Tal vez por ello, por la inmensidad de ese escenario, Grecia acaba por naturalizar todo lo humano. Sin embargo, en un giro profundamente romántico, es el conocimiento de la propia esencia lo que abre el camino a la ciencia desde una perspectiva judía. Es el modo en que este ser especial establece relaciones interpersonales con la divinidad lo que marca el inicio del estudio de lo natural. El pueblo judío parte de una posición superior en el análisis de lo real, confía en su Dios y se sabe único dentro de lo existente, pues se concibe a sí mismo como un ente a medio camino entre el Creador y el resto de lo creado. pp. $73-75$.

${ }^{1}$ S. Rosenberg, El bien y el mal en el pensamiento judio. Barcelona, Riopiedras, 1996, 2 Ibidem, p. 77. 
A diferencia de Grecia, su esencia no se equipara en ningún momento al resto de lo natural: la Naturaleza es una entidad diferente, aunque próxima (Ps 8, 4-7). Dios escondió en ella las trazas necesarias para alcanzar el conocimiento del auténtico y único objeto de estudio para la especie humana, que no debe ser otro que la propia divinidad, a cuyo lado y bajo cuya protección aspira a residir.

Esto obliga a definir y precisar el marco de las relaciones hombre-mundo, pues se trata de un escenario que ha fluctuado a lo largo de la historia del judaísmo. Martin Buber, en 1916, ofrece desde su propia perspectiva de intelectual judío una visión muy clarificadora y moderna acerca de la actitud humana frente al mundo. Buber nos habla de un encuentro interpersonal y basado en la adquisición de conocimiento entre el ser humano y su Dios, es decir, de mí a ti, de Yo a Tú ${ }^{3}$ y a través de todo, en todas partes ${ }^{4}$. Todo permite a la criatura conocer a Dios a través de su obra. La esencia del judaísmo jamás vetará el conocimiento; antes bien, fomenta ese esfuerzo, por cuanto que forma parte de lo rubricado por Abraham ante Dios en nombre de todo su pueblo. Es el espíritu que impregna nuestra propia mística hispana a través de versos como los del Cántico espiritual de san Juan de la Cruz: «iOh, bosques y espesuras, plantadas por la mano del Amado! ${ }_{j} \mathrm{Oh}$, prado de verduras, de flores esmaltado! Decid si por vosotros ha pasado».

La visión de Buber o de los filósofos modernos y contemporáneos sobre la actitud humana en el uso de su inteligencia frente a lo real desconocido supone un cambio trascendental, pues objetiva la naturaleza exterior y hace extensivo al resto de la humanidad ${ }^{5}$ lo que tan solo era válido para el judaísmo. La ciencia judía medieval carece en realidad de ese carácter ecuménico que comienza a aparecer tímidamente con los cambios culturales del Renacimiento. Hasta la Edad Moderna, el judaísmo se amolda a los sistemas y clasificaciones del conocimiento establecidos en el entorno, aun cuando su objetivo esencial solo afecte al espacio hebreo. Resulta injusta la imagen alegórica de una Sinagoga con ojos vendados que camina, como las otras religiones monoteístas, en pos de la verdad.

\section{LA CIENCIA EN EL MUNDO JUDÍO ANTIGUO: DE BABILONIA A ALEJANDRÍA}

El sistema científico judío va definiéndose como consecuencia de la exégesis talmúdica y la interacción con los otros sistemas de pensamiento del entorno. La elite intelectual deportada a Babilonia en el siglo vi a.C. y los escritos resultantes configuran en buena medida la relación del Israel anterior al Medievo con las ciencias. Su expresión en los textos sagrados del exilio señala el inicio de una actitud

3 Ver M. Buber, Yo y tú. Madrid, Caparrós, 2005.

${ }^{4}$ H. KüNG, El judaísmo. Pasado, presente y futuro. Madrid, Ed. Trotta, 1993, p. 549.

5 J. Habermas, Israel o Atenas. Ensayos sobre la religión, teología y racionalidad. Madrid, Trotta, 2011, p. 198. 
marcada por lo sagrado, pero veteada de guiños profanos, sin los cuales muy probablemente el yahvismo no habría configurado de forma tan perfecta su monoteísmo ${ }^{6}$.

La ciencia, en especial la matemática, se desarrolla en Mesopotamia a partir del segundo milenio antes de Cristo como una consecuencia de la necesidad de controlar las aguas y poner en cultivo las tierras de las riberas fluviales. El propio desarrollo agrícola propició el avance en las ciencias de la medición del tiempo. La astronomía, como observación, anotación y presagio de los fenómenos celestes, parece preceder a la consolidación de la astrología, que añade a todos esos datos precisos la posibilidad de su interpretación como indicios de futuro. Toda la ciencia matemática y astronómica fue conocida perfectamente por la comunidad judía en el exilio, pero esta rechaza algo tan habitual desde el siglo v a.C. como el uso del conocimiento científico para el trazado de horóscopos y cartas astrales con un carácter mágico y condicionante. Lo esotérico está reñido con la idea de un Dios todopoderoso y benefactor que suprime el fatalismo con su providencia.

Para un pueblo nómada, carente de agricultura y de tantas otras cosas, la matemática no venía a resolver ningún problema de cultivos o distribuciones territoriales. Es cierto que a la altura de la Edad Media o de la Moderna, muy a pesar de la prohibición expresa, en las artes cabalísticas también se hizo uso de ensalmos y talismanes para conjurar la nefasta influencia de los espíritus del mal, pero ello no podía significar en absoluto que se cuestionase la voluntad divina. Por tal motivo, este tipo de prácticas de naturaleza mágico-propiciatoria necesitaban un revestimiento de carácter científico que las legitimase también a ojos de la oficialidad religiosa, ocultando su naturaleza heterodoxa.

Es la definición de sus propios conceptos de tiempo y espacio, en todo momento referidos a su Dios, lo que de algún modo obliga a la adopción de estos saberes, forzando su arraigo y posterior desarrollo, como un acto de amor y acatamiento de las leyes divinas. Para un concepto temporal lineal y dirigido, como es el formulado y legado por la cultura grecolatina, el concepto cíclico y proyectado hebreo puede resultar algo complejo. Tiene su origen en la coincidencia de la división espacial y temporal en grados sexagesimales ${ }^{7}$ que Mesopotamia utilizaba para ordenar su vida y que había nacido de la observación directa. La conciencia de los ciclos de 360 días, repetidos año tras año, condicionó ese concepto del tiempo en que absolutamente todo se actualizaba una y otra vez y pese a ello no se encerraba en sí mismo como un uroboros, permitiéndose el avance y la proyección a un futuro más perfecto.

Este concepto condiciona evidentemente la percepción histórica del pueblo de Israel y se conjuga por necesidad con la aceptación de la voluntad y providencia divinas. Dios, dueño absoluto de tiempo y espacio, ha pedido al ser humano que

${ }^{6}$ P. SACCHI, Historia del Judaísmo en la época del Segundo Templo. Madrid, Trotta, 2004, p. 74 .

7 G. Schiaparelli., Scritti sulla Storia della Astronomia antica, vol. I. Bolonia, Associazione Culturale Mimesis, 1925, p. 47 y ss. 
en un acto de valentía camine en la creación para descubrir por sí mismo la esencia de su divinidad, de la completa realidad. A cambio, Él se compromete a dejar las pistas necesarias para proseguir la búsqueda y a cuidarle y orientarle, incluso con el castigo, hacia la verdadera meta de una vida perfecta y plena. Es por esto por lo que el avance no puede quedar atrapado en lo repetitivo: el ciclo es un acto de consolidación de lo ya avanzado y continuidad en la adquisición de más conocimiento. La experiencia queda así incorporada a este modelo temporal repetitivo y se actualizará periódicamente. La concepción del ciclo temporal anual de 360 grados o días obligaba al reajuste de los calendarios solar y lunar con la inclusión de esos cuatro días y pico más, que, considerados al margen, no parecen formar parte del tiempo, constituyen una realidad temporal sin tiempo ni espacio, como lo será el sábado judío, una paradoja solo comprensible desde una mentalidad religiosa. Tal vez, el hábito de incorporar al cómputo ese segundo mes de Adar condujo a admitir que el tiempo así concebido permanecía abierto y que era posible incorporar en él nuevos hitos significativos para todo el pueblo, hitos pasados que, merced al ciclo, eran actualizados cada vez y vividos como presentes.

La importancia de marcar hitos sobre esta línea cíclica dirigida y proyectada al futuro que es el aprendizaje de la realidad, conmemorarlos y celebrarlos, origina una literatura específica muy temprana (entre los siglos in y i a.C.) de carácter científico. No obstante, esta producción, como El Libro de las luminarias celestiales contenido en el Libro de Enoc o el Libro de los Jubileos, fue entendida como suplementaria, desplazada y no incluida entre los libros testamentarios por la mayoría de las comunidades hebreas o cristianas. El judaísmo no puede proscribir de ninguna manera aquello que constituye su propia esencia: la comprensión de lo existente: «Examinemos nuestros caminos, escudriñémoslos, y convirtámonos a Yahveh» (Lam 3, 40).

\subsection{LA CIENCIA BÍBLICA COMO SISTEMA MORAL. LOS LÍMITES DE LA CIENCIA}

Religión y ciencia participan en principio de idéntica búsqueda de la verdad. Cuando la verdad es absoluta y revelada, como sucede en el judaísmo, la ciencia parecería carecer de sentido y, sin embargo, es una religión que impele al fiel a practicar las artes del conocimiento y del aprendizaje. Dios hace una revelación velada y espera de su criatura que realice el esfuerzo de aprender y comprender los misterios que le conduzcan a esa verdad absoluta que constituye parte de su esencia. El texto sagrado no es más que una guía a seguir en esa tarea humana.

El pacto entre Abraham y su Dios asienta las bases de un proceso de autoformación en que el ser humano contará con el texto revelado como manual y con el premio y el castigo que, como expresión de la providencia divina, le servirán para controlar su avance mientras asume su libre albedrío. Por eso, los ojos de este aprendiz se vuelven al texto, como objeto puramente físico (interpretación literal) en primer lugar, pero también como fuente de conocimiento (exégesis). El conflicto entre ciencia y religión es una mera construcción humana que surge de una elección errónea entre las posibles interpretaciones del texto que encierra la revelación. Por esta causa se hace necesario ese mecanismo corrector y orientador constituido por el sis- 
tema de premio y castigo. El judaísmo no puede ni sabe desligar el conocimiento de sus consecuencias y entiende que estas son además calificables dentro de un baremo graduado entre lo positivo y lo negativo.

El Génesis sitúa al ser humano por encima del resto de la creación (Gn 1, 26) desde el momento en que es concebido como imagen trazada a semejanza y a voluntad de Dios. Está llamado a gobernar sobre esa creación, pero debe hacerlo como Dios lo haría, esto es, de una forma sabia y consciente. Su similitud comporta la adquisición de análogas características divinas y compromete su actuación: debe actuar de modo responsable y consciente, con conocimiento, pues, como Dios, tendrá que definir su voluntad. No obstante, toda elección implica la adopción de una posición susceptible de ser juzgada, instalada en algún punto entre lo acertado y lo erróneo. La humanidad está legitimada para dominar la naturaleza (Gn 9, 1-15) y escudriñar cada uno de sus secretos.

El conocimiento y el avance científico o técnico es en cierto modo un cumplimiento de la voluntad divina respecto a su criatura. La imposición deriva de esa similitud con Dios, que en ningún momento le otorga la capacidad de decisión sobre algo que no le pertenece: puede por tanto conocer hasta el último secreto y valerse de ello, pero nada puede alterar, puesto que todo responde a un plan trazado por alguien superior a él. Y, aun así, cuenta con el don de la libertad, aunque esta quede limitada al formar parte de una relación, no solo con su Dios, sino con el resto de lo creado, que de algún modo ha pasado a depender de él. El decálogo del Sinaí es una llamada de atención sobre las posibilidades de caída en lo confuso. La humanidad debe asumir que su actuación equivocada tiene consecuencias también nefastas para esa relación con el medio que le rodea, consigo mismo y, por ende, con su Dios. Pese a su libertad, debe saber que su elección errada solo aporta la violencia y la inversión del orden establecido. El propio texto sagrado, que pone en manos del ser humano todo lo creado, le limita y le responsabiliza de todo lo que suponga trasgresión y ruptura haciendo de su capacidad de conocimiento una elección de tipo moral.

\subsection{El Mito del Sabio JUdío: La literatura bíblica SAPIENCial y Rabínica}

No solo el decálogo o la actuación puntual de los jueces y profetas ayudan a Israel en su camino. La literatura sapiencial, desde dentro del propio texto sagrado, configura la clave para esa actuación humana en la búsqueda del conocimiento de lo real. Deben considerarse por igual tanto la literatura canónica, como el Qohelet (Eclesiastés), como la no incluida pero tenida en cuenta en los comentarios rabínicos, como el Sirácida (Eclesiástico). Ambas forman parte del acervo moral hebreo. El vínculo entre sabiduría, intervención y consecuencias es entendido en el judaísmo como un acto ético. La ciencia nace así lastrada por este acto y los libros sapienciales ofrecen las reglas del juego $(S i 1,26)$ para el comportamiento del ser humano ante sí mismo, su grupo y la naturaleza entera (Si 43, 32-33). «Toda la sabiduría viene del Señor» (Si 1,1), pero esto no implica en absoluto que la experiencia del ser humano no sea necesaria como fuente de conocimiento. 
Durante buena parte de la historia de la humanidad, hablar de ciencia o de filosofía significaba lo mismo. Ambas partían de la necesidad humana de comprensión y control del entorno. Incluso parece que la orientación científica de ese conocimiento, tal y como sucede en Grecia, antecede a lo filosófico, que vendría a consistir en una profunda reflexión acerca de los datos obtenidos de la observación directa. El judaísmo no es muy diferente en su modo de actuar, aunque lo haga sobre objetos diferentes. Su reflexión utiliza como material básico lo revelado, no lo observado, de manera que, aun con la certeza de su verdad por proceder directamente de Dios, se hace precisa una constatación previa de todo lo que constituye el punto de partida. La reflexión sobre el texto sagrado produjo un tipo de conocimiento aplicado a esa verificación: la literatura sapiencial y rabínica. Esta literatura reflexiona sobre lo divino, pero también sobre lo natural, por eso es al judaísmo lo que la ciencia o la filosofía es a Grecia.

No obstante, la literatura sapiencial plantea un problema a muchos teólogos, ya que parece abandonar el carácter nacional que vertebra el resto de los escritos, que gira en torno a la idea del pacto, para ubicarse en una esfera de lo genéricamente humano: no es el judío el único destinatario de estas enseñanzas, sino el hombre como especie inteligente en su conjunto. Estos libros y los comentarios rabínicos derivados son en realidad una especie de cuadernillos de prácticas de laboratorio en que se han de aplicar las enseñanzas teóricas del Pentateuco, las normas y reglas establecidas por Dios. El lenguaje de estos libros y el usado por los comentaristas postexílicos sobre todo hacen también accesible esa teoría a los no versados en leyes o a los desconocedores de los arcanos de la realidad ya desvelados.

Aunque la aparición de esta literatura del conocimiento esté vinculada a la elite cultural apegada a la monarquía y la huella de la influencia egipcia se haga evidente, no podemos dejar de rastrear en ella un sustrato de origen tribal muy anterior $^{8}$ que también forma parte de su esencia. En los textos sapienciales, como es el caso de los Proverbios de Salomón, encontramos una definición de la sabiduría profundamente moral. El saber está intrínsecamente unido a las cualidades morales más deseables (Prov 10, 31) y es a su vez fuente clara de otras muchas ideas que completan la perfección humana y que encaminan los pasos del hombre a la felicidad. La sabiduría emana de Dios (Prov 2, 6), el sabio es un instrumento de Dios para comunicarse con su criatura y poder darle directrices a fin de que permanezca en la senda correcta (Prov 2, 10-12). Es además una expresión providencial del amor de Dios por su criatura y la trama unitiva del universo creado. La sabiduría es también el elemento que mantiene el orden del universo y acerca el ser humano a Dios cuando hinche su espíritu?.

${ }^{8}$ R.E. Murphy, «Hebrew wisdom». Journal of the American Oriental Society, vol. 101, núm. 1 (1981), p. 26.

9 J.J. Collins, «Cosmos and salvation: Jewish wisdom and apocalyptic in the Hellenistic Age». History of Religions, vol. 17, núm. 2 (1977), pp. 121-142, p. 125. 
El concepto de sabiduría que se maneja (המכוח-Hokhmah, en hebreo) en la literatura talmúdica es el propio ya de un conocimiento científico, al menos opera como tal, a excepción del hecho de que la base no surge de la observación directa, sino que es fruto de una revelación. Por esta causa, la verdadera ciencia bíblica se construye solo en el transcurso del tiempo, cuando la observación directa y la evolución en la aplicación de esos argumentos revelados permiten a los observadores poner por escrito en sus comentarios interpretativos las conclusiones a las que han llegado y que los capacitan para entender el espíritu de la Ley. Ser sabio en el Israel antiguo es en realidad ser capaz de interpretar el alma del texto, y esa capacidad surge solo de la habilidad en el uso del sentido común ${ }^{10}$. Israel liga de esta manera el concepto de sabio al de intérprete de los designios divinos, concediendo incluso un lugar preeminente a la profecía como parte del sistema de conocimiento.

Los textos bíblicos están llenos de pinceladas que resultan tremendamente actuales para dibujar lo que debe ser considerado un hombre sabio y destacar sus características. Los sabios del Talmud se dedicaban en cuerpo y alma a la tarea de dilucidar en el texto sagrado instrucciones más precisas que ayudasen a vivir de acuerdo a lo pactado con Dios, pero se encontraban con la dificultad de tener que armonizar una Ley inmutable con una realidad vital cambiante ${ }^{11}$ a cada segundo. En verdad esa será la mayor muestra de su sabiduría, ofrecer la cuadratura perfecta del círculo. Su labor no era por tanto una obligación personal contraída por su propio sentimiento religioso, sino que, por el contrario, consistía en un compromiso hacia el resto del pueblo. La sabiduría debía trascender al individuo dotado de aptitudes, superar su subjetividad produciendo un beneficio social, y este se materializaba en el servicio a la comunidad como maestro y como juez experto en la ley religiosa. El conocimiento es fundamentalmente un don individual que genera una obligación comunal, de manera que enseñar y juzgar nunca pudieron convertirse en tareas de carácter lucrativo ${ }^{12}$. Este vínculo entre sabiduría y obligación de enseñar queda establecido en el judaísmo desde los primeros momentos.

El hombre de ciencia, con conocimiento, reflexiona sobre lo aprendido y aporta nuevos puntos de vista. Como señala Mario Bunge, quizás su principal aporte radica en la capacidad de ofrecer una visión más ordenada y comprensible de lo real para permitir al ser humano domeñar lo creado del modo en que su Dios le exige: "Por medio de la investigación científica, el hombre ha alcanzado una reconstrucción conceptual del mundo que es cada vez más amplia, profunda y exacta» ${ }^{13}$. El orden, la regularidad que se esconde tras la norma y convierte lo natural en una ley, nace de la comprensión de la verdad de esa realidad y debe ser precisado como parte del marco en que se inscriben las relaciones entre Dios y su creación. La ruptura del

${ }^{10}$ J.F. Priest, «Where is wisdom to be placed?». Journal of Bible and Religion, vol. 31, núm. 4 (1963), pp. 275-282, p. 276.

${ }^{11}$ C. Herranz Pascual, Los sabios del Talmud. Barcelona, Riopiedras, 1997, p. 9.

12 Ibidem, p. 56.

${ }^{13}$ M. Bunge, La ciencia. Su método y su filosofía. Pamplona, Laetoli, 2013, p. 6. 
orden como consecuencia del desconocimiento es castigada ${ }^{14}:$ «La ciencia del sabio crecerá como inundación, y su consejo será fuente de vida. El interior del necio es como un vaso roto, que no retiene ningún conocimiento. Si un hombre de saber oye palabra sabia, la elogia y otra suya añade. Si la oye el libertino, le desagrada y la echa detrás de sus espaldas» (Si 21, 13-14). La expresión lógica y ordenada de lo real subyace por igual en los intentos de una filosofía griega y en los comentarios rabínicos.

El sabio judío que trabaja con los textos sagrados tampoco aspira a demostrar, sino a verificar, pues es un tipo de científico más fáctico que formal ${ }^{15}$. Se trata de un intelectual que constata casos experimentales nacidos de la interactuación entre el hombre y Dios, antes de proponer una explicación racional y objetiva. Dicha explicación es un acto deductivo que surge del contraste entre los conceptos del análisis y las reglas lógicas derivadas del estudio de la revelación.

Los sabios del Talmud, como científicos, buscan la verdad, pero «no consideran su propia experiencia individual como un tribunal inapelable; se fundan, en cambio, en la experiencia colectiva y en la teoría ${ }^{16}$. Tampoco abordan la realidad como un todo, sino que la analizan y descomponen tratando de identificar y dar nombre o solución a cada problema concreto. Aunque contemplen la posible intervención del azar, se basan siempre en el conocimiento de las soluciones anteriores para aportar nuevos enfoques y esta es una de las características de la ciencia, la acumulación de saberes y producción de más saber. No obstante, su labor principal no es la investigación, sino la transferencia de lo ya conocido a quien sea considerado digno de poseer tales conocimientos. De ahí su mayor preocupación por establecer una forma adecuada y fidedigna de transmisión, que recurre a menudo al uso de las sentencias breves a modo de píldoras del saber. Por estas causas y aunque nos resulte sorprendente, la actuación de los exégetas judíos es también una labor científica.

La figura del sabio judío acabará por convertirse en un mito para el saber de la Edad Media y de la Moderna. Flavio Josefo ya intentaba presentar a Abraham como una figura de mente preclara, especialmente dotado para el pensamiento lógico, formado en los centros más importantes del saber de su época, casi como un filósofo griego o un científico a la usanza mesopotámica, capaz de alcanzar la noción de la existencia del Dios único gracias a su propio discurrir y de entablar cualquier discusión con los sabios egipcios ${ }^{17}$ e incluso de transmitirles sus propios conocimientos de astronomía y matemáticas ${ }^{18}$. Pero Flavio Josefo, que presenta a Moisés ${ }^{19}$ de idéntica manera, fija las características de ambos héroes nacionales como propias de todo su pueblo. El vínculo del sabio judío con las fuentes más primitivas del conocimiento de origen divino acaba por investirle de un cierto carácter dogmático y mítico

${ }^{14}$ R.E. Murphy, «Hebrew wisdom», p. 26.

${ }_{15}$ M. Bunge, La ciencia, p. 9.

${ }^{16}$ Ibidem, p. 12.

17 L.H. Feldman, "Abraham the Greek philosopher in Josephus». Transactions and Proceedings of the American Philological Association, vol. 99 (1968), pp. 143-156, p. 153.

18 Ibidem, p. 154.

19 Flavio Josefo, Antigüedades judias. Libro II, Capítulo XII, Sección 4. 
reforzado por la sugerente idea de su origen oriental y por tanto mistérico ${ }^{20}$. El propio Flavio Josefo hace alusión a un pasaje donde se narra tal vez la primera oposición que se establece entre Grecia y el mundo hebreo: el relato de Clearco de Solos ${ }^{21}$ acerca del encuentro entre Aristóteles y un sabio judío, Hiperoquidas. Clearco presenta a Aristóteles admitiendo que, en el intercambio de ideas, él recibió más de lo que aportó. En ese relato podemos encontrar tal vez una antigua razón de la vinculación del conocimiento judío con el mundo oriental y su carácter mágico, pues se hace a los judíos descendientes de la casta de brahmanes de la India o de la casta de magos de Persia ${ }^{22}$. Esto explicaría quizás la generalizada vinculación de los judíos con los saberes mistéricos que tuvo lugar por parte de la intelectualidad a lo largo de toda la Edad Media e incluso después.

La figura del sabio judío se benefició del aura de admiración con que la Grecia prehelenística rodeó la ciencia y el conocimiento oriental. Grecia necesitaba justificar su avance en el saber a través del contacto con esos otros focos de la geografía antigua e ideó un sistema de viajeros en ambas direcciones que contribuyó a la transmisión del pensamiento y el considerable desarrollo científico. Así que, en cierto modo, con su reconocimiento de la sabiduría, fuese cual fuese su procedencia, Grecia configuró para Occidente el mito del sabio judío de características orientales, pero al que no se niega jamás su capacidad. La discusión entre fe o razón será por tanto muy posterior. El judaísmo medieval supo aprovechar muy bien esta pasión griega por lo oriental y acrecentó su propio interés por la filosofía, que nunca se vio como algo ajeno. Bastaba con dar la vuelta a la historia y presentar a los griegos como aprendices del pensamiento mosaico, incluso difundiendo la idea de un Aristóteles converso tras ver la luz entre los libros de Salomón que Alejandro le manda custodiar ${ }^{23}$.

Pero la consideración de la extraña alianza entre el estudioso judío y el saber es tan hija de los tiempos medievales como de las construcciones, más o menos interesadas, que surgen en los tiempos de la Sinagoga Triunfante tras la Haskalá, muy a menudo entre las páginas y declaraciones de autores no judíos. Cuando Lessing escribe su Nathan der Weise (1779), no hace solo un alegato a favor de la tolerancia religiosa, sino que asienta, sobre el patrón de su amigo Moses Mendelssohn, el arquetipo del nuevo judío ilustrado, admirado y rechazado por igual en la Europa contemporánea. El intento de Lessing de clarificar la imagen del sabio judío no consigue empero su objetivo. Una imagen heredada de la medievalidad que nos presenta un personaje siempre oscurantista e intrigante, taimado y egoísta, solo al servicio de sus propios intereses, como el Shylock de Shakespeare (The Merchant of Venice, 15961599), contrasta enormemente con el dibujo de libre pensador empeñado en buscar

20 S.J. Whitefield, «The Jew as wisdom figure». Modern Judaism, vol. 13, núm. 1 (1993), pp. 1-24, p. 2.

${ }_{21}$ Flavio Josefo, Contra Apión. Libro I, 177-181.

${ }^{22}$ H. Lewy, «Aristotle and the Jewish Sage according to Clearchus of Soli». The Harvard Theological Review, vol. 31, núm. 3 (1938), pp. 205-235, p. 211.

${ }^{23}$ I. Abrahams, «Aristotle in Jewish philosophy». Mind, vol. 13, núm. 51 (1888), pp. 468472, p. 469. 
la armonía entre las tres religiones y asentar la fraternidad en la similitud de todos los seres, desvaneciendo las diferencias entre ellos. El recorrido entre la imagen de un «astuto» judío egoísta y la figura del «sabio» altruista es no solo la distancia entre las diferentes concepciones de «ser humano» a lo largo de la Europa Moderna, sino que marca igualmente la condición indispensable para el nacimiento de una ciencia contemporánea universalista a favor de la especie y no ya al servicio de la Corte y de la empresa cortoplacista.

La medievalidad, salvo contados episodios de cohabitación como Sefarad, construyó muros espesos entre las religiones y creó amplias áreas de desconocimiento de las creencias del otro en el seno de cada una de las sociedades monoteístas. Probablemente fue el miedo a los cambios que esa conciencia del otro podría introducir en los propios esquemas consolidados, pero lo cierto es que ese temor construyó también imágenes grotescas y caricaturescas, cuando no infantiles e insostenibles desde la razón. La imagen que nos presenta del judío el arte medieval, vista desde nuestra posición actual, es una imagen risible y, sin embargo, ha perdurado formando parte de la justificación antisemita. La realidad del sabio judío es muy distinta: «Se trata de un concepto y meta de sabio y sabiduría en que se mezcla lo divino y lo humano, lo teórico y lo práctico, la ciencia con la moral, la filosofía con la vida práctica y cotidiana, el logro del éxito y la felicidad en este mundo y en el más allá tras la muerte ${ }^{24}$. Como todo parece indicar, el sabio es alguien conocedor de lo sagrado y lo profano, llamado a la enseñanza y la dirección del grupo, con un claro dominio de sí mismo y la felicidad como objetivo básico.

\section{EL SISTEMA DE LAS CIENCIAS EN EL JUDAÍSMO MEDIEVAL Y MODERNO}

\subsection{A vueltas CON El CONFlicto ENTRE FE y RAZÓN}

Desde el siglo xix la historiografía científica ha presentado a la religión como el principal obstáculo para el avance del conocimiento. El judaísmo no permaneció al margen de esta confrontación, pero para el mundo judío decimonónico «ciencia» implicaba sobre todo la presión absorbente por parte de un entorno cristiano empeñado en su asimilación dentro de un sistema de vida más laico. Sin embargo, a lo largo de la historia, el judaísmo se caracterizó precisamente por mantener una postura de superación y conciliadora con lo que significaba ciencia en cada momento. Maimónides, su explicación natural del aristotelismo y lo que ello supuso para el conocimiento hebreo medieval y moderno son una buena muestra de este comportamiento.

${ }^{24}$ J. Lomba Fuentes (ed.), Ibn Gabirol, Ibn Paqûda, Pedro Alfonso. Dichos y narraciones de tres sabios judios. Zaragoza, Mira Editores, 1997, p. 14. 
Una de las mejores fuentes actuales para el estudio de esta cuestión durante la Edad Media es el libro de Y. Tzevi Langermann ${ }^{25}$ The Jews and the Sciences in the Middle Ages. Langermann nos advierte a través de estos estudios de los reparos de los rabinos medievales hacia cualquier conocimiento que pudiese entrar en contradicción con la Torá, pero analiza pormenorizadamente de qué manera, sin embargo, el discurrir científico se incorpora a la producción de Abraham bar Hiyya, Judah ibn Verga y Bahya ibn Paqudah, para quienes la armonía entre ambos es un lugar común ${ }^{26}$, Judah ha Levi, autor según Langermann de una auténtica cosmología hebrea de orden neopitagórico y orientación neoplatónica ${ }^{27}$; Hasday Crescas... El mundo judío no parece dar la espalda a la ciencia y prueba de ello son las numerosas traducciones que se hacen de obras científicas cristianas o musulmanas al hebreo, a fin de facilitar su estudio, y por supuesto las tempranas incorporaciones que los comentaristas talmúdicos hacen de informaciones científicas babilonias desde muy pronto, configurando el germen de la posterior literatura científica hebrea ${ }^{28}$.

La mirada vinculada al sentimiento aportada por la religión ${ }^{29}$ ha sido considerada tradicionalmente como algo plural, multifacético, abstracto y cambiante en función de la cultura; de ahí que se apostase siempre por el enfoque científico, capaz de ofrecer una visión más estable, uniforme y, cuando menos, libre de la problemática que origina la posible existencia de interpretaciones varias ${ }^{30}$. La oposición se convirtió casi en dogma de fe, especialmente para los intelectuales modernos que consideran el tamiz religioso como un lastre para el avance de la especie. Por eso, cuando Shestov, en 1951, reformuló geográficamente ${ }^{31}$ esta eterna contraposición entre dos formas distintas de ver la realidad, Atenas y Jerusalén, tan solo constataba una tensión histórica e irresoluta, iniciada muchos siglos atrás. Shestov, sin embargo, ejerce una dura crítica al racionalismo y ofrece una posibilidad a la fe y la espiritualidad como vía de conocimiento. El sabio no puede confiar en su propia inteligencia sin apoyarse en Yahveh (Prov 3, 5): se trata de una elegante forma de superación de un conflicto que en realidad jamás pareció tener lugar. Leo Strauss, por ejemplo, parecía entender inicialmente la oposición entre helenismo y hebraísmo como una lucha de opuestos sin posible punto de encuentro ${ }^{32} \mathrm{y}$, sin embargo, algo más ade-

25 Y.T. Langermann, The Jews and the Sciences in the Middle Ages. Variorum Collected Studies Series. Brookfield, VT, Ashgate Publishing Company, 1999.

${ }^{26}$ Ibidem, p. 42.

${ }^{27}$ Ibidem, p. 44.

${ }^{28}$ Y.T. Langermann, «Science in the Jewish communities», en D. Lindberg y M. Shank (eds.), The Cambridge History of Science, Cambridge, Cambridge University Press, 2013, pp. 168189, p. 169.

${ }^{29}$ R.L. Johnstone, Religion in Society: A Sociology of Religion. Upper Saddle River, NJ, Prentice Hall, 1997, p. 13.

30 J.H. Evans y M.S. Evans, «Religion and Science: Beyond the epistemological conflict narrative». Annual Review of Sociology, vol. 34 (2008), pp. 87-105, p. 90.

${ }^{31}$ L. Shestov, Afiny i Ierusalim. París, YMCA Press, 1951.

${ }^{32}$ L. Strauss, The Rebirth of Classical Political Rationalism. An Introduction to the Thought of Leo Strauss, Essays and Lectures by Leo Strauss, Selected and Introduced by Thomas L. Pangle. Chi- 
lante acabará comprendiendo a través de la filosofía medieval que la obra de algunos filósofos hebreos no puede explicarse sin Grecia y que la Edad Media supuso ese trasvase necesario de un modo a otro, aunque fuese tímidamente mediante el recurso a una escritura de tipo esotérico ${ }^{33}$.

El conflicto entre revelación y filosofía que se plantea en el judaísmo es heredado por las otras religiones del libro. Todas ellas acabarán por encontrar una solución similar para resolverlo y para expresarlo: la firme creencia en que la palabra revelada aúna una doble realidad. Existe un sentido interno oculto que debe ser esclarecido a la luz de la inteligencia y cuya explicación a veces solo es posible mediante el uso del símbolo y la alegoría, desde una posición velada o esotérica. Este tipo de indagación requiere de la cooperación a lo largo del tiempo y acaba por generar la tradición (תרוסמ-masoret), pues no es tarea para una sola persona todo lo que implica un aprendizaje de ideas y formas y su asociación debe ser transmitida así a las siguientes generaciones. Pero existe también un sentido literal, evidente, que no requiere de interpretación alguna, pues trascribe directamente la palabra divina.

\subsection{Clasificación de las Ciencias y CONSIDERACión DEL aRTE}

Las ciencias medievales fueron durante mucho tiempo un objeto de estudio de segunda fila. Obnubilada por los logros de la ciencia moderna desde el Renacimiento, la historiografía no supo ver que es en esos siglos oscuros cuando se configura la base que facilitará ese deslumbramiento cultural posterior ${ }^{34}$. Desde el siglo XII, superados algunos momentos de rigor religioso por la tímida apertura carolingia, comienzan a adquirir su propia autonomía los estudios de las cosas de la naturaleza, algo más al margen de la teología y disfrazados bajo lo que se conocía como Filosofía Natural. Estos estudios significaban la recuperación de los textos griegos originales y su posibilidad de discusión, y, aunque a menudo ya habían sido vertidos al latín, se hacía necesaria la traducción de toda una producción posterior a la que el sector occidental del Imperio no había tenido acceso.

La labor de los scriptoria en los monasterios y el acercamiento a esa ciencia griega perdida gracias al contacto con el islam, que había realizado la traducción de muy buena parte de esa sabiduría clásica, harán posible que la Europa Occidental recupere y vuelva a asentarse sobre una base esencial de su cultura. En el sector oriental del Imperio y las tierras bajo el islam, la Edad Media supuso no solo el mantenimiento de la riqueza cultural grecorromana, sino su acrecentamiento y profundización, ya que no se produjo el sesgo brutal impuesto por la llegada de los pueblos germanos. Las primeras traducciones al árabe de textos médicos, de alqui-

cago, University of Chicago Press, 1989, p. 72.

33 R. Brague, "Athens, Jerusalem, Mecca: Leo Strauss's 'Muslim' understanding of Greek Philosophy». Poetics Today, vol. 19, núm 2 (1998), pp. 235-259, p. 242.

${ }^{34}$ E. Grant, The Foundations of Modern Science in the Middle Ages: Their Religious, Institutional and Intelectual Contexts. Cambridge, Cambridge University Press, 1996. 
mia y de astrología mantuvieron vivos unos saberes que entroncaban con una antiquísima ciencia nacida a medio camino entre el Oriente mesopotámico y el Occidente mediterráneo. La Iglesia no supo ver en ellos su valor científico y despreció su aporte, en unas ocasiones proscribiendo textos y en otras ridiculizando a sus autores. El cristianismo se autosanciona renunciando a una de las bases de su razón de ser: el pensamiento griego.

El judaísmo oriental, sin embargo, cuya relación con lo griego había sido más pacífica que con lo romano, ve prosperar su situación económica, social y cultural entre los siglos viII y x, con el uso del griego, el árabe y el hebreo como lenguas francas. Si Alejandría representaba la adopción del helenismo, Bagdad significaba la modernidad a la luz del avance islámico, tomando Jerusalén y los centros de estudio del mundo conocido como campo de batalla. La revolución en el pensamiento judío que se produjo entre caraítas y partidarios de la tradición rabínica obligó a una toma de postura definitiva en el seno de esta comunidad ante el tema de la razón y su disputa con la fe y, por ende, ante el tema de la ciencia y el conocimiento. El mutazilismo islámico ejerció igualmente alguna influencia en estas disputas internas, que acabarán resolviéndose con la superación conciliadora de Maimónides y posteriores filósofos premodernos como Gersónides.

El judaísmo juega un papel fundamental en esas tareas de recuperación cultural durante el siglo XIII principalmente, no solo como intermediario mediante la traducción del árabe en centros como la Escuela de Traductores de Toledo, sino mediante la profundización y aporte de nuevas visiones y conocimientos. La extraordinaria red de comunicaciones que mantienen entre sí las distintas comunidades judeoeuropeas constituyó un sistema útil para la difusión de la ciencia en general, no solo la producida en ambiente hebreo. El sistema de comunicación epistolar, de pregunta y respuesta, permitió a la comunidad hebrea adelantarse a las otras religiones en el tratamiento de determinadas cuestiones científicas ${ }^{35}$, ofreciendo incluso soluciones a algunos de los interrogantes planteados. Los responsa rabínicos que circulaban entre sinagogas de toda Europa frecuentemente dan noción de la preocupación judía por estar al tanto de cualquier avance y saber si este afecta en algo la cotidianeidad de su vida religiosa ${ }^{36}$. Estos responsa, que permiten la adopción al unísono de posturas similares por toda la comunidad, se comportan a menudo como las mejores revistas científicas de la época. Estos textos evidencian hasta qué punto la religión y cualquier otro aspecto vital estaban unidos: la ciencia no se entiende fuera del alcance de la religión, ya que afecta a la vida del ser humano judío y, por tanto, también a su modo de entender el mundo, un sistema profundamente religioso. La gran autopista del saber que fue también el Camino de Santiago se superpone y complementa esta otra vía de comunicación epistolar.

${ }^{35}$ J. RoIz, A Vigilant Society: Jewish Thought and the State in Medieval Spain. Albany, State University of New York, 2013, p. XI.

${ }_{36} \mathrm{M}$. Orfali, «Los responsa rabínicos y la vida interna en las aljamas aragonesas». Aragón Sefarad, vol. 1 (2005), pp. 161-175, p. 162. 
La crítica a la que se someten desde el siglo xiII el método de Aristóteles y los textos clásicos recuperados sirvió de impulso para alcanzar nuevas fronteras, así como para la configuración de otras distintas formas de mirar al mundo. Lo curioso de este ambiente es el trasiego de información que se opera al margen de lo teológico entre filósofos naturales de las tres religiones monoteístas, pues todos ellos supieron entender que la realidad es idéntica independientemente del dios que sea considerado su creador. De esta manera, el método empírico, de raigambre aristotélica y propuesto por la escolástica cristiana, no podrá entenderse ya sin la apuesta por la lógica y la experiencia que el islam y los intelectuales judíos habían rescatado de entre las bases del pensamiento griego. Era este un pensamiento empeñado a todas luces en presentarnos una naturaleza sometida a leyes asumibles por la razón. El islam rescata toda esa visión matemática de las cosas de la naturaleza que el pensamiento aristotélico rechazaba por no responder a las causas que buscaba y por considerar que solo era capaz de constatar esencias.

Pero el mundo islámico medieval no solo transmite conocimientos de Grecia a la cristiandad europea renacentista ${ }^{37}$, sino que, en esa labor propia de conciliación de fe y razón, fue capaz de reelaborar y ampliar el conocimiento recibido marcando de algún modo el camino a las otras dos grandes religiones. Parecía lógico que en ese ambiente surgiese una figura que, como Maimónides, dedicara su empeño a la tarea de dotar también al judaísmo de una guía para evitar el desdén por una forma de conocimiento tan válido ${ }^{38}$, armonizándola además con el ámbito de lo religioso, donde todo se hacía girar alrededor de la palabra revelada. Este ambiente hebreo era en sí una escena realmente profana, donde la religión marcaba especialmente el carácter político del fiel como ciudadano de estados donde eran minoría.

Para el judaísmo tradicional, todas las ciencias tenían cabida en la Torá, única fuente de verdad. Ningún rabino pondría en duda o rechazaría, sin embargo, lo que la experiencia certifica, pero las ciencias contenidas en lo revelado no son en absoluto producto de la reflexión filosófica o la razón, sino que se refieren al conocimiento de lo natural ${ }^{39}$. La clasificación de las ciencias admitida comúnmente entre los judíos de la Edad Media establecía en principio dos tipos de saberes muy diferenciados, aunque conectados entre sí por el texto revelado: los saberes de lo físico sensible y aquellos de lo espiritual e inaccesible. A medida que ambas ramas del saber se desarrollan y se establecen puentes válidos entre ellas, se consolida un tercer grupo de conocimientos de muy extraña consideración y entre los cuales tendrá cabida el mundo de lo mágico propiciatorio, pues este goza de una naturaleza híbrida a medio camino entre lo físico y lo sobrenatural. La evolución de este tipo de ciencia requirió el cambio de concepción renacentista en el sistema de relaciones

${ }^{37}$ A. SABRA, «The appropriation and subsequent naturalization of Greek science in medieval Islam: A Preliminary Statement». History of Science, vol. 25 (1987), pp. 223-243, p. 224.

${ }^{38}$ J. RoIz, A Vigilant Society, p. 3.

39 C. Sirat, A History of Jewish Philosophy in the Middle Ages. Cambridge, Cambridge University Press, 1990, p. 410. 
entre el ser humano, la naturaleza y Dios, al convertir lo creado en una fuente de información al mismo nivel que la del texto revelado.

El cuerpo de las ciencias consideradas como tales entre los judíos medievales era relativamente extenso y complejo, tanto que Moshe Sefardí se vio prácticamente obligado a comienzos del siglo XII a poner algo de orden, desde su propio punto de vista ${ }^{40}$, incluyendo siete artes liberales ${ }^{41}$ : lógica-dialéctica, aritmética, geometría, medicina-física, música y astronomía, que suman un total de seis, más la que según unos era la nigromancia o ciencia de lo oculto y, según otros, la gramática. Sefardí no sigue la separación tradicional de saberes de trivium y quadrivium. De sus textos deducimos lo importante que es para él la matemática como base de otros conocimientos y la necesidad de conectarlos todos, pues unos ayudan al desarrollo de los otros: acepta la influencia de los astros en las cosas mundanas, como la salud, y justifica por ello determinadas actuaciones médicas en función de la astrología y sus principios. No todo el pensamiento judío podía convenir con la idea de considerar la nigromancia como una ciencia más, dado el clima aristotélico casi generalizado; por eso no puede extrańarnos que muchos, como Maimónides, las calificaran de patrañas y simplezas.

Abraham bar Hiyya nos ofrece en sus Fundamentos de la inteligencia y torre de la creencia otra clasificación que, aun coincidiendo en su mayor parte con la de Moshe Sefardí, complica y especifica aún más el elenco de saberes, al considerar cuatro grupos diferentes: las ciencias didácticas, con una base matemática; las de la física de los seres naturales o cuerpos simples; la política o humana; y, finalmente, la divina ${ }^{42}$. Esta división nos habla en realidad de la impronta religiosa en la organización de las ciencias, pues si prestamos atención, el primer bloque estaría compuesto por los saberes instrumentales que permiten acercarse al conocimiento de la creación en un orden ascendente hacia Dios: de la naturaleza al ser humano y de este a Dios. En el ámbito de la matemática se integrarían, pues, disciplinas tales como la aritmética, geometría, álgebra y astronomía. Esta era especialmente cuidada y considerada por su relación con el cómputo del tiempo y la confección del calendario religioso, la intercalación o 'ibbur, una necesidad vital para la comunidad judía, lo que motivó en parte el gran desarrollo alcanzado en su seno.

La consideración de las artes y los artistas en este maremágnum del conocimiento solo podemos inferirla a través de pequeñas pinceladas. No fue un tema que ocupase durante el Medievo a quienes prestaron atención a la clasificación de los otros saberes, pero la proximidad de los tiempos modernos sí hará que al menos se retomen y redefinan ideas bastante originales y que pudieron condicionar en algo las discusiones de los primeros teóricos e historiógrafos renacentistas. Abraham ibn Ezra expone la manera en que el mundo y las actividades humanas son influencia-

\footnotetext{
40 D. Romano, La ciencia hispanojudia. Madrid, Mapfre, 1992, p. 89.

${ }^{41}$ Ibidem, p. 26.

42 Ibidem, p. 100.
} 
dos por los astros ${ }^{43}$. La protección planetaria se ejerce de manera muy especial sobre el pueblo de Israel, que en lo tocante a la astrología debe sentirse privilegiado por expreso deseo de Dios (Jr 10,2). Las diferentes labores, remitidas a la protección de tal o cual planeta, adquieren así las características que como arquetipo definían a cada uno de ellos. Curiosamente, las artesanías y la práctica del dibujo, el grabado y la pintura se adscriben a la esfera de Mercurio, en la que además se integraban, amén del comercio, la práctica de la filosofía, la matemática o la geometría. Ibn Ezra, a diferencia de lo que fue habitual durante los siglos siguientes, no adscribe la pintura a la influencia de Venus, planeta al que quedaba vinculada cualquier manifestación estética ${ }^{44}$. Lo interesante de su distribución es sin duda la consideración de las artes plásticas como actividades intelectuales, de manera análoga a lo que luego hará Vasari en la Florencia del siglo XvI.

Básicamente, podríamos establecer la clasificación siguiente de los saberes tradicionales y modernos: las ciencias de lo físico sensible, las ciencias de lo espiritual e inaccesible y las ciencias propiciatorias, organizadas a su vez por las particularidades de su finalidad y objeto.

Las ciencias de lo puramente físico nada tienen que ver con la filosofía o con la razón. Están presentes ya en el texto revelado, no son en absoluto una creación humana, por lo que el hombre nada aporta a su método de estudio. Este tan solo lo ejerce y lo hace en aras de un mejor conocimiento de la obra del Creador y son, por consiguiente, la base fundamental para acceder a Él a través de su obra. La Edad Media aspiraba al conocimiento íntegro de la creación en su conjunto, pero la imposibilidad de cumplimiento de este objetivo determinará el viraje experimentado desde el Renacimiento, cuando los intelectuales judíos comprendan que las cosas de la filosofía en nada menoscaban las cosas de la fe y que ambos saberes son complementarios y no antagonistas. No obstante, especialmente en los siglos medievales, aún podríamos establecer dentro de este apartado dos grupos distintos en función de su relación con el propio ser humano, el tipo de utilidad a que corresponden o su objeto de estudio:

- Ciencias naturales esenciales: derecho, medicina, astrología, matemática y alquimia. Saberes profanos relacionados con lo ético, lo cognitivo inmediato y hasta lo estético. Equivalentes de algún modo al concepto árabe de $a d a b^{45}$. - Artes prácticas: agricultura y metalurgia. Artes en general.

43 A. Ibn Ezra, The Beginning of Wisdom. Eds. R. Levy and F. Cantera. Londres, Oxford University Press, 1939, p. 200.

${ }_{44}$ L. Campos Ribeiro, «The children of Mercury: The image of the artist and the scientist in medieval astrological texts and iconography», en M.A. Miranda y A. Miguélez Cavero (eds.), Portuguese Studies on Medieval Illuminated Manuscripts, Barcelona-Madrid, Fédération Internationale des Instituts d'Études Médiévales, 2014, pp. 131-144, p. 139.

45 J. Lomba Fuentes, El Ebro: Puente de Europa. Pensamiento musulmán y judio. Zaragoza, Mira Editores, 2002, pp. 94-95. 
Las ciencias de lo espiritual e inaccesible, como la cábala, venían a suplir la carencia de explicación de un origen divino en lo real que los filósofos pasaban por alto, tan preocupados como estaban en la constatación y mensura de lo existente. Ofrecían también al ser humano judío unas indicaciones válidas para el cumplimiento de su misión ${ }^{46}$, tomando en consideración una tradición oral que servía de expresión válida a la sabiduría del pueblo de Israel.

La alquimia judía como ciencia más o menos propiciatoria y efectiva pudo tener su arranque entre los textos de la Meteorológica de Aristóteles, más concretamente en sus capítulos III y Iv. En ellos se procede a la descripción de los cuatro elementos, los efectos del calor y el frío sobre los cuerpos del mundo sublunar en constante proceso de cambio ${ }^{47}$ y la identificación de los metales como compuestos de dos principios, más tarde asimilados al azufre y el mercurio ${ }^{48}$ y cuyo análisis y posibilidades originarán todos los tratados y recetarios de época medieval. La alquimia judía, a tenor de los textos conservados, se desarrolla, sin embargo, con posterioridad al mundo medieval, pues durante toda la Edad Media los discursos que se traducen y que se producen apuntan a una magia más teórica que práctica ${ }^{49}$. Todo lo relacionado con este tema, salvo la astrología, que contaba con un prestigio reafirmado por la tradición, era oficialmente rechazado.

La eclosión de las ciencias naturales durante el Renacimiento determinará que la frontera entre magia y alquimia se desdibuje y dé inicio a un estudio serio. Señala Rafael Patai que el interés de los judíos por la alquimia es bastante secundario, pues en realidad surge motivado por contactos con su entorno no judío. Su momento más excelso lo marca el siglo xIv, cuando los textos hebreos dedicados a esta ciencia se hacen más numerosos ${ }^{50}$ ante la necesidad de responder a una disminución en el tráfico y disponibilidad de metales preciosos.

Lo cierto es que el interés judío en la alquimia ni fue general ni parece ser significativo, por más que entre los padres y madres de esta ciencia se cite a aquella mítica alejandrina de comienzos de nuestra era, María la Judía, inventora de técnicas como el baño maría u objetos de laboratorio como el alambique de dos o tres brazos (dibikos, tribikos). Los textos de alquimia presentan una ciencia a medio camino entre la teoría y la práctica, pero la complejidad filosófica retrocede en ellos para lograr una mayor claridad expositiva muy próxima a los textos científicos modernos. Durante toda la Edad Media no hubo una diferenciación real entre la alquimia y la química y hasta casi el siglo XIX se consideró que la química también trataba casi con exclusividad de la trasmutación de los metales.

${ }^{46}$ J. RoIz, A Vigilant Society, p. 211.

47 A. Barrero, «El aporte de Aristóteles a la Meteorología». Meteorología Colombiana, vol. 8 (2004), pp. 107-113, p. 110.

${ }_{48}$ W.R. NeWMAN, «What have we learned from the recent historiography of Alchemy?». Isis, vol. 102, núm. 2 (2011), pp. 313-321, p. 315.

49 C. Sirat, A History of Jewish Philosophy, p. 410.

${ }^{50}$ R. Patai, The Jewish Alchemists: A History and Source Book. Princeton, NJ, Princeton University Press, 1994, p. 174. 


\section{JUDAÍSMO HISPANO, CIENCIA Y MEDIEVALIDAD}

La valoración del aporte del judaísmo a la ciencia comienza justamente con Flavio Josefo y la defensa que hace del mismo en sus Antigüedades judías. La validez de su objeción a la opinión de Apión acerca del genio hebreo ${ }^{51}$ o la de Apolonio Molón ${ }^{52}$ se hará evidente por sí sola a lo largo de toda la época medieval.

En Sefarad, donde actuaron a menudo como intermediarios en la comunicación científica entre cristianos y musulmanes, participaron diligentemente de los proyectos y empresas iniciados por los sabios de estas otras comunidades, como Alfonso X. Mediante sus traducciones al hebreo ${ }^{53}$ supieron hacer llegar también a sus correligionarios de la Provenza y norte de Italia los frutos de este peculiar clima cultural sefardí, especialmente todo el corpus de saberes islámicos, a los que el resto de la Europa cristiana no tuvo un acceso tan directo. Esta preocupación es más que patente en obras como las de Abraham bar Hiyya, quien en la primera mitad del siglo XII reúne y traduce con un claro sentido didáctico y eminentemente práctico los saberes más importantes para los judíos franceses ${ }^{54}$, o en las noticias que tenemos de otros personajes como Abraham ibn $\mathrm{Ezra}^{55}$, uno de los mejores creadores de terminología científica en hebreo $0^{56}$ y el primer matemático judío en usar el sistema decimal. En la segunda mitad del siglo XII, Ibn Ezra difunde además el uso del astrolabio y los saberes matemáticos árabes en Italia, Francia e incluso Inglaterra. El judaísmo hispano participa así en la ciencia europea hecha en latín: no solo traducía textos adoptados como manuales en las universidades, alumbraba también otros de producción propia, con una orientación científica moderna que contrasta con la vaguedad de las artes medievales.

El alcance de lo que hoy llamamos ciencia hispanojudía debe ser matizado geográfica y conceptualmente. Lo hispanojudío no coincide exactamente con los límites políticos actuales. Hasta la Edad Moderna, la producción científica hebrea tiene en la Península Ibérica y el norte de África sus dos zonas esenciales, pero a España y Portugal habríamos de sumar la zona del sudeste francés, el sur de Italia e incluso el norte de África. A menudo es en estas regiones y gracias al continuo intercambio con ellas donde fructifica lo mejor de la ciencia de los judíos españoles.

La consideración de tres culturas diferentes en una Hispania como la medieval o premoderna no es más que un tópico que ayuda a comprender la existencia

51 Flavio Josefo. Obras completas de Flavio Josefo. Ed. Luis Farré. Buenos Aires, Acervo Cultural, 1961, vol. 5: Contra Apión, II, p. 135: «Pero no tuvieron hombres admirables, que hayan sido innovadores en las artes o que se distinguieran por su sabiduría', dice Apión».

52 Ibidem, p. 148: «Además dice que somos los más ineptos de los bárbaros; y que por esto no hemos hecho ninguna contribución al progreso humano».

53 Y.T. Langermann, «Science in the Jewish communities», p. 172.

54 D. Romano, La ciencia hispanojudia, p. 95.

55 Y.T. LANGermanN, «Science in the Jewish communities», p. 172.

56 S. Sela, «La creación del mundo supralunar según Abraham ibn Ezra: un estudio comparativo de sus dos comentarios a Génesis 1, 14». Sefarad, vol. 63 (2003), pp. 147-181, p. 156. 
de tres religiones forzadas a coincidir en un mismo suelo donde, en esencia, ni la convivencia fue tal ni hubo más que una cultura común del conocimiento, innegablemente asentada sobre una pujante y predominante base científica islámica. Así, para algunos, como Joaquín Lomba, el pueblo hispanojudío participó, tanto en zona musulmana como cristiana, de la única cultura que en aquel momento habia, la musulmana ${ }^{57}$. En un espacio donde las fronteras imperaban para lo político, pero no así para lo intelectual, la cultura se configura como geografía común, merced tanto al aporte oriental semita como a los procesos de debate que este sufre. No carece de sentido imaginar una cultura hispana surgida con la diferencia religiosa como marco, pero reorientada por el debate hacia lo genérico y no hacia la divergencia. La ciencia hispana medieval parece hecha por expertos filósofos y doctores en lo religioso y lo que llamamos ciencia hispanojudía no es sino ciencia hecha por hispanos, cuya peculiaridad consistía en profesar la fe judía, pero que como tales estaban al tanto de lo que cristianos y musulmanes pensaban respecto al mismo tema. La cábala, por ejemplo, manifiesta una necesidad común con cristianos y musulmanes: el misticismo. Ni la respuesta había de ser muy diferente ni constituía un gran problema aprender del modo en que los vecinos la redactaban. Si es posible hablar de una ciencia hispanojudía, lo es paradójicamente por una característica fundamental de este pueblo: su unidad en la dispersión y el uso del hebreo como lengua común entre comunidades diferentes. Las relaciones comerciales y, muy curiosamente, el Camino de Santiago contribuyeron en esta difusión de la ciencia entre hebreos de un confín al otro de Europa, llegando incluso a los grandes centros islámicos norteafricanos u orientales.

\subsection{Algunos aspectos al margen de los nombres propios}

La historia de los hispanojudíos es la historia de Hispania: su producción científica no puede desligarse de la de estos territorios. Los documentos que argumentan un interés científico en los primeros siglos medievales entre los judíos hispanos son pocos; no hubo un aporte especial, pero fueron cimiento necesario. Fue una época de gran inestabilidad en que estaban definiéndose territorios y voluntades y la comunidad judía era minoritaria. Sus esfuerzos, en estos inicios medievales, se dirigen sobre todo a la aclimatación a los cambios del entorno, esto es, a vivir entre musulmanes tras la dura etapa visigoda o a vivir entre cristianos a medida que avanza la reconquista o el rigorismo islámico determina la emigración al norte. Tres centros del saber judío mantendrán su influjo a lo largo de cambios de poder y época: Toledo, Zaragoza y Sevilla ${ }^{58}$. Nada podría entenderse sin episodios previos

57 J. Lomba Fuentes, El Ebro: Puente de Europa, p. 133.

58 J. Samsó, Las Ciencias de los antiguos en Al-Andalus. Madrid, Editorial Mapfre, 1992, p. 126. Samsó destaca la especialización de los mismos: si a Toledo y luego a Sevilla. les concede el dominio de la astronomía y la agronomía, hace de Zaragoza el centro matemático por excelencia, cuya importancia completa J. Lomba con los estudios de medicina, lógica y botánica farmacológica. 
como las academias de Córdoba (siglos IX-x) y Lucena, cuya inspiración en materia religiosa, filológica y exégesis bíblica y talmúdica sirvió de faro a todo el judaísmo mundial del momento. Pero nada se justifica tampoco sin el papel desempeñado por una población bastante viajera que actúa como vehículo de transmisión entre los grandes focos culturales del momento: Damasco, Alejandría, Cairuán, Germania... De allí vienen ideas y allí acuden en su busca los grandes científicos y pensadores hispanojudíos como Maimónides.

Dos ciencias destacan entre los judíos andalusíes, la medicina y la astrología, cultivadas por atractivas personalidades que animarán nuestra propia versión del mito del sabio hebreo aliado del poder, especialmente durante el período de los Reinos de Taifas. Médicos como Hasday ibn Saprut (915-970) de Jaén, al que encontramos tratando la hidropesía de Sancho I el Craso de León a instancias de su abuela la reina Tota de Navarra. Hasday acrecienta el interés por la farmacopea en el Califato, pues, junto con el monje bizantino Nicolás, tratará de averiguar la equivalencia en árabe de los nombres de las sustancias simples que integraban los medicamentos recetados en el ejemplar del Dioscórides, manuscrito en griego, que el emperador de Bizancio había enviado a Abderramán III. Fueron casos como el de Semuel Ibn Nagrella en Granada y su pequeño círculo intelectual o Yequtiel ibn Hasan en Zaragoza.

El Califato y los períodos de Taifas fueron científicamente fructíferos para el judaísmo, pero el rigorismo almohade da al traste con el edificio cultural alzado y obliga a la ciencia judía bajomedieval a desarrollarse en ambiente cristiano. La comunidad hebrea de Al-Andalus, mermada su influencia política y culturalmente debilitada, poco puede aportar ya. Desde el siglo xiI se multiplica el número de juderías en tierras cristianas, al tiempo que la Iglesia adopta una posición de abierta intolerancia frente a este ciudadano judío culto, preparado y osado en las empresas de carácter económico, pero propiedad personal del rey en la mayor parte de las ocasiones. El estatus especial de estos personajes allegados a las cortes se hace evidente en 1215 con las resoluciones del IV Concilio de Letrán, pero la obligatoria rodela que había de ser visible en la parte superior izquierda del vestido con frecuencia no era lucida por quienes estaban al servicio directo del rey. Funcionarios, médicos y algunos científicos parecían quedar exentos de tales distinciones.

El siglo XIII marca una diferencia en la condición de judío en las dos grandes coronas hispanas. En Aragón, el desarrollo de la burguesía y de una clase cada vez más culta y preparada permite la sustitución de los judíos en el funcionariado, pero Castilla siguió echando mano de sus judíos como elite cultural y administrativa, pese a serles vedado el acceso a las incipientes universidades, tal y como sucedía también en el resto de Europa. Su formación se produce en el seno de la familia, que funciona también como pequeño taller de ciencias donde aprender bajo la dirección personal de un maestro, o bien a instancias de la propia congregación religiosa, utilizando quizás la infraestructura de las escuelas talmúdicas a modo de escuela privada hebrea.

Desde mediados del siglo XIII, la documentación existente sobre la relación de los judíos y las ciencias es mayor, en parte porque se intensifica el uso de las lenguas romances. A veces son textos aljamiados que limitan el acceso al saber, pero 
también son traducciones directas del árabe hechas por judíos. La producción científica más significativa de este momento se da en el ámbito de la astronomía y la cartografía, con el astrolabio y las técnicas de medición como objeto principal. Entre los astrónomos más destacados hemos de citar a Abraham Zacuto (1452-1515), un personaje que unía sin problema la práctica de la astronomía con la de la astrología y al que Manuel I de Portugal, en 1496, antes de la partida de Vasco da Gama, pide que adiestre en el conocimiento del astrolabio y el cielo a los marinos, pero que prediga igualmente el resultado de la expedición.

No obstante, la medicina continuó siendo el campo científico por excelencia, aunque la profesión se aprendiera al margen de la Universidad, ejerciendo desde el principio junto a un maestro cualificado, de un modo casi gremial. El manejo de los textos árabes era fundamental y, curiosamente, salvo en la zona de Cataluña ${ }^{59}$, no hubo un gran aporte escrito en realidad. Su condición de infieles les impedía por prohibición papal ejercer con pacientes cristianos, pese a ser los más reputados y disputados en las cortes hispanas. Esto les granjeaba ciertas prebendas, una cierta posición social y reconocimiento.

Junto al médico judío, era frecuente ver en las cortes hispanas otra figura, a veces coincidente, de gran autoridad y relacionada con lo esotérico: el astrólogo real, como Cresques de Viviers en la corte de Juan I de Aragón. Los esfuerzos en la alquimia y la nigromancia de los judíos de la Corona aragonesa también obtienen su reconocimiento en personajes como Menahem de Mallorca. El máximo exponente hispánico de la contribución hebrea a la ciencia ${ }^{60}$ es sin duda la Escuela de Traductores de Toledo. Pero el mapa no estaría completo sin Gerona y su escuela cabalística, iniciada y desarrollada por Bonastruc ça Porta, Nahmánides. El siglo XıII es la época dorada de la exégesis bíblica y talmúdica que consolida el ambiente místico y cabalístico. El viaje de formación y estudio a Sefarad comienza a ser materia obligada en otras áreas del entorno europeo y mediterráneo.

\subsection{LA CIENCIA Y EL ARTE DE LA CREACIÓN: LAS ARTES DEL LIBRO}

El libro judío no proscribe la imagen, pero prima la grafía. El valor que la letra asume en el programa cosmogónico hebreo como elemento de creación reviste al libro de un carácter sagrado y hasta divino. Ya el Sefer Yetzirah o Libro de la Creación intenta una explicación más o menos coherente del acto creador llevado a cabo por Dios mediante letras y sefiroth, las 32 vias maravillosas de la sabiduría. El valor simbólico depositado en el alefato, letras que son números y viceversa, fue sin duda, en un principio, un instrumento válido de comprensión que el desarrollo cabalís-

59 D. Romano, La ciencia hispanojudia, p. 127.

${ }^{60}$ Ibidem, p. 133. Cinco de sus doce miembros (Yehuda ben Moshe ha Kohen, Ishaq ben Sayyid, Abraham de Toledo, Semuel ha-Levi y Don Moshe) eran judíos e intervinieron en 23 obras del total de la producción. 
tico posterior acabó desvirtuando hasta convertirlo en algo de naturaleza mágica. La escritura se vio investida con valores propios de la imagen, asumiendo sus funciones. Se llega incluso a convertir la línea de escritura en una adecuada línea de dibujo para salvar hábilmente prohibiciones tácitas, aprehensiones y reparos hacia el mal uso de la representación de lo real. La micrografía de los caligramas hebreos permite remitir a lo creado más que representarlo, evitando la soberbia de equipararse al Dios creador.

Frente a la caligrafía árabe que ligaba y deformaba letras para asemejar imágenes, la caligrafía hebrea se veía impedida para deformar lo que fueran los instrumentos creadores de Dios; las letras permanecen cuadradas, completas, y solo se deforman para crear unas grafías con que aludir y nombrar lo que no tiene representación ni nombre posible: Dios. Tal y como sucede en la decoración epigráfica de El Tránsito en Toledo, donde el alef y el lamed de la palabra ל-Dios acaban convirtiéndose en un símbolo híbrido inexistente en el alefato.

Los escribas son personajes afamados entre los intelectuales hebreos; su misión requiere una especial preparación y un reconocimiento de su moral íntegra por parte de toda la comunidad. Son simbólicamente los artistas más próximos al acto creador divino, por cuanto que usan la escritura de la palabra y la materializan, sin ella la realidad no existiría. De manera análoga a las familias de iluminadores, los escribas se organizan en talleres familiares, seguramente itinerantes, que llevan consigo no solo su arte, sino un cierto ejercicio de gusto, y, por supuesto, transmiten conocimientos allá donde se afincan. Es el caso del clan sefardí de Toledo de los Ben Israel ${ }^{61}$.

Lo llamativo de estos libros, incluidas las biblias, pese a su reticencia a la imagen, es el modo tan natural en que armonizan lo religioso y los avances científicos del momento. Algunos, como la incorporación de calendarios, son necesarios para el perfecto desarrollo del culto, máxime teniendo en cuenta la especial naturaleza solilunar del cómputo litúrgico hebreo. Pero son los libros científicos ilustrados los que ponen sin duda el arte al servicio de la difusión del saber: las ilustraciones científicas hablan de la colaboración de escribas e iluminadores de diferente religión $^{62}$. La colaboración entre los sabios de las tres religiones hispanas muestra sin reservas la interinfluencia de estilos artísticos y gustos. Millard Meiss llega incluso a atribuir alguna de las imágenes de la copia de 1348 de la Guía de los perplejos de Maimónides, en Copenhague y procedente de Barcelona, al propio maestro catalán Ferrer Bassa ${ }^{63}$. Todo estaba al servicio del mejor arte, aunque las prácticas cris-

${ }^{61}$ G. Sed Rajna et al., L'art juif. París, Citadelles \& Mazenod, 1995, p. 224. Isaac ben Israel es el autor de la escritura de los volúmenes de la Biblia dividida entre la Biblioteca de Marsella y San Petersburgo (ms. 1626/ II-III de la Biblioteca de Marsella y ms. II.53 de la Biblioteca de San Petersburgo). Hayyim ben Israel, copia la Biblia de 1277 que se encuentra en la Biblioteca Palatina de Parma (ms. parm. 2668).

${ }^{62}$ C. Roth, The Jews in the Renaissance. Filadelfia, The Jewish Publication Society of America, 1977, p. 190.

${ }_{63}$ G. Sed Rajna et al., L'art juif, p. 225. 
tianas del libro, de la decoración de espacios de culto y de la orfebrería sagrada acabasen ejerciendo restricciones y prescindiesen de esa colaboración, sobre todo en época moderna. En ocasiones, esta presión del entorno conducía al artista judío a la conversión, que era entendida como única vía de escape y se convertía en garantía de prosperidad.

La relación entre arte y ciencia fue y será siempre muy estrecha, al menos en lo que respecta a la historia de la cultura de base grecolatina, de la que se nutre por igual la tradición judeoeuropea hasta nuestros días. Cierto es que la mayor parte de las fuentes y documentos que nos servirían para corroborar esta afirmación pertenecen a la Edad Moderna y que en los siglos precedentes apenas unos simples recetarios, como el atribuido frecuentemente a Abraham ibn Hayyim sobre la fabricación de pigmentos, nos permiten calibrar esa correspondencia. Del análisis pormenorizado de ese texto podríamos colegir los conocimientos de química y hasta de alquimia sagrada o magia que un artista judío del siglo Xv estaría dispuesto a mostrar. Se trata del único texto de origen hebreo relacionado con la práctica de las artes visuales. Procedente de la Península Ibérica, se conserva hoy en la Biblioteca Palatina de Parma (MS 1959), donde llegó con el lote de la colección de Giovanni Bernardo de Rossi.

Sin entrar en la disputa de adscripciones cronológicas y geográficas en función de los estudios lingüísticos ${ }^{64}$, lo cierto es que el recetario nos presenta objetos y sustancias más propios de un laboratorio alquímico que del taller de un iluminador ${ }^{65}$. Luis U. Afonso y A.J. Cruz hacen hincapié en el curioso vínculo alquímico, que se desarrolla especialmente en los tres primeros capítulos y el capítulo veintinueve ${ }^{66}$, entre los nombres de los metales utilizados y los planetas ${ }^{67}$.

La iluminación de libros judíos se desarrolla en condiciones muy desiguales en Europa. La especificidad de la letra hace necesaria la intervención de un escriba hebreo y condiciona muchos aspectos formales, como la composición de la imagen, pero la ilustración no tenía que surgir necesariamente de entre los dedos de un iluminador judío. La existencia de un texto como el de Hayyim y su propio apellido, que encontramos vinculado a este arte a lo largo de generaciones y en lugares diferentes como la Península Ibérica o Italia ${ }^{68}$, corroboran de alguna manera la existencia de un saber especializado que se trasmite familiarmente de generación en

${ }^{64}$ L.U. Afonso, "New developments in the study of $O$ livro de como se fazen as cores das tintas", en L.U. Afonso (ed.), The Materials of the Image. As Matérias da Imagem, Lisboa, Cátedra de Estudos Sefarditas Alberto Benveniste da Universidade de Lisboa, 2010, pp. 4-7. Luis U. Afonso hace un preciso y certero análisis de las diferentes teorías, antes de analizar la estructura y profundizar en los contenidos de esta obra.

${ }^{65}$ Ibidem, p. 8.

${ }^{66}$ A.J. Cruz y L.U. Afonso, «On the date and contents of a Portuguese medieval technical book on illumination: O livro de como se fazem as cores». The Medieval History Journal, vol. 11, núm. 1 (2008), pp. 1-28, pp. 22-23.

${ }^{67}$ L.U. Afonso, "New developments in the study of $O$ livro de como se fazen as cores das tintas», p. 8.

${ }^{68}$ C. Rотн, The Jews in the Renaissance, p. 193. 
generación y la existencia de talleres itinerantes, quizás por las circunstancias, que persisten en la práctica de tan noble arte.

Los recetarios medievales son un nexo perfecto entre arte y ciencia y un indicador preciso del modo en que la ciencia es aplicada a los diferentes órdenes de la vida. Pero este recetario hebreo en concreto tiene la habilidad de unir ciencias medievales habituales con saberes específicamente judíos. Su parentesco con otros recetarios anteriores puede advertirse solo en la estructura y organización, pero no tanto en los contenidos. Esto revela necesariamente otras fuentes al margen de los saberes artísticos habituales en la Europa Central altomedieval no compartidos con talleres extraibéricos y fruto de una ciencia esencialmente hispana, del encuentro de avances técnicos cristianos e islámicos ${ }^{69}$.

La preparación de los pigmentos medievales aúna arte y ciencia, pero también la ciencia esotérica al margen de la pura química. Los colores se invisten de un significado preciso $^{70}$ que con frecuencia deriva de la naturaleza mágica o especial de su ingrediente principal ${ }^{71}$, como es el caso del lapislázuli, el bermellón o el carmín de gomalaca, considerados productos de lujo. Prepararlo era por tanto conocer también esos secretos y aplicarlo, hacer uso de sus propiedades propiciatorias. Esto nos permite observar el objeto artístico con otros ojos muy distintos a los de la simple mirada estética, pues el modo en que se han obtenido los colores y sus propios componentes enriquecen considerablemente el significado de un texto ilustrado.

En la iconografía y la composición de las ilustraciones de buena parte de las biblias cristianas producidas en Hispania, se observa la presencia de motivos y recursos muy antiguos, que nos conducen a pensar en la influencia de antiguos ciclos bíblicos judíos llegados de Oriente y que constituirán un aporte esencial al arte del libro medieval. El discurso narrativo analítico de la imagen que ya se encontraba en los frescos de Dura Europos y que se relaciona con la exégesis rabínica vuelve a aparecer en estas biblias del siglo $\mathrm{XIV}^{72}$, indicando que no hubo fronteras para el arte judío, que mantuvo estrechos lazos durante toda la Edad Media con el Oriente; y que tampoco debieron de existir para una ciencia de acento oriental, que alcanzará su definición más pura al otro cabo del Mediterráneo, en Occidente.

La posible estrecha colaboración entre artistas judíos y cristianos con posterioridad a los tiempos medievales, al margen de los círculos intelectuales de discusión, tampoco fue nunca tan feliz como cabría pensar. Una vez que los caminos del arte comienzan a institucionalizarse a partir de las academias, al judío no le queda más opción que adquirir su formación en los talleres de los reputados maestros cristia-

${ }^{69}$ A.J. Cruz, «Em busca da origem das cores de 'O Livro de Como se Fazem as Cores': sobre as fontes de um receituário portugués medieval de materiais e técnicas de pintura», en L.U. Afonso (ed.), The Materials of the Image, p. 76.

70 J. Wirth, L'image à l'époque romane. París, Cerf, 1999, pp. 382-385.

71 M.A. Miranda y M.J. Melo, «Secrets et découvertes en couleur dans le manuscrit enluminés», en M.A. Miranda y A. Miguélez Cavero (eds.), Portuguese Studies on Medieval Illuminated Manuscripts, p. 11.

${ }^{72}$ G. Sed Rajna et al., L'art juif, p. 226. 
nos, pues de otro modo sus posibilidades de triunfo se veían limitadas a un público pudiente exclusivamente judío o a los encargos por parte de la comunidad hebrea.

\section{A MODO DE CONCLUSIÓN}

La ciencia hebrea no va a remolque de ninguna otra: difunde y crea, aporta decisivamente temas y enfoques diferentes. No obstante, durante buena parte de la Edad Moderna, su desarrollo corre paralelo y precisa de la interacción con la producción científica de cristianos y musulmanes. La similitud temática y la variedad de puntos de vista es lo que hace de esta ciencia moderna un logro humano general y no adscrito específicamente a una religión o cultura.

La ciencia en el judaísmo adquiere pronto un valor moral que la condiciona durante todo su desarrollo. Tal vez este carácter derive del hecho de que todo lo conocible sea revelado a través de un texto sagrado que actúa también como código ético. El conocimiento no se otorga al ser humano de un modo explícito y cerrado, sino que su codificación entre las líneas del texto exige del ser humano un esfuerzo por adquirirlo. Su Dios le ha hecho a su imagen y semejanza y, por tanto, un ser racional, pero el pecado cometido desobedeciendo sus leyes por el deseo de un mayor conocimiento que le equipare al creador introduce también entre sus facultades la fantasía. Esta nueva facultad distorsiona la realidad y le obliga a mantenerse alerta en aras de un conocimiento científico veraz y no falseado.

Solo la naturaleza, reflejo material de Dios, le servirá de modelo de corrección en esta tarea de adquirir el conocimiento por sus propios medios. Hasta la Edad Media, Israel consideró siempre esta empresa como propia, aunque se acomodase a los modos científicos comunes y generales. Solo los siglos de la Edad Moderna traerán consigo una visión más ecuménica, considerando que el aporte del judaísmo puede ser igualmente válido para el resto de la humanidad.

Como en otros pueblos de la Antigüedad, la ciencia hebrea pudo iniciar su desarrollo de la mano de la agricultura y la sedentarización. Sin embargo, en el Israel antiguo, la auténtica alianza con el conocimiento científico parece establecerse a partir de la necesidad de un rígido cómputo y control del tiempo por motivos litúrgicos. Los conceptos de tiempo y espacio, que actúan de marco en cualquier proceso científico, adquieren en el mundo judío una definición especial, pues quedan acotados por la dimensión de la relación que se establece entre el pueblo y su Dios.

Hasta la época moderna, el saber judío se desarrolla dentro de los límites marcados por la Torá y la práctica religiosa. El mito del sabio judío, configurado entre las líneas de una literatura sagrada sapiencial y acrecentado por la admiración helenística, sobrevive a la Antigüedad clásica y se nos presenta a las puertas de la Edad Moderna como paradigma de una ciencia que siempre discurrió entre lo físico y lo moral. Pese a esta peculiaridad emanada de su doble naturaleza, el científico talmúdico era ya un científico moderno que hizo de lo empírico y del análisis atomizador su método de reflexión. No le fue difícil por eso, llegado el tiempo de la Haskalá o Aufklärung, mostrarse como un personaje ilustrado más, racional y con- 
secuente con los tiempos modernos, donde ya no reinaba el sol del oscurantismo, sino el de los derechos del ser humano y los principios revolucionarios.

La Ilustración sobreviene al judaísmo, después de resolver previamente la aparente relación imposible entre fe y razón mediante una sutileza sintética: la revelación encerraba un sentido interno oculto que solo la razón podría hacer aflorar a la superficie del saber. Esta consideración, que también heredaron las otras ciencias surgidas al amparo del monoteísmo, dibujó en buena medida el sistema judío de saberes. El orden de los conocimientos contempló hasta la Edad Moderna tres grupos bien marcados con métodos y recursos propios bien definidos: lo físico tangible, lo espiritual inaccesible y lo propiciatorio.

En el mapa de conocimientos hebreo que se despliega en la Hispania medieval tendríamos que situar muchos nombres personales cuya luz alcanza todo el orbe conocido hasta el momento, pero también disciplinas que, como la astronomía, la matemática o la gramática, se convirtieron en puntales de referencia ante la comunidad judía mundial y el saber practicado por cristianos y musulmanes. En esa estructura de conocimiento, el arte, tal y como hoy lo entendemos, también halla su sitio: no solo como soporte de transmisión a través de la ilustración miniada en libros de los saberes más variados o de la propia escritura, sino que se impregna él mismo de ese halo de ciencia y sabiduría, convirtiendo las técnicas en auténticos modelos científicos.

La preparación de los pigmentos necesarios para la ilustración de códices y manuscritos, por ejemplo, no puede entenderse al margen de los avances de la química y la alquimia, el enlace necesario con el mundo de lo propiciatorio. Nada es casual, como revelan los recetarios medievales, y todo en el arte responde al deseo de hacer gráfico y de representar plásticamente la unidad de todo lo creado, sea cual fuere su naturaleza: física o espiritual, tangible o sobrenatural. Hacer arte en el judaísmo fue durante mucho tiempo un modo de hacer ciencia y solo en los tiempos modernos, cuando la ortodoxia religiosa confinada en los guetos y shtetlej resucita la eterna polémica en torno a la imagen, el artista vuelve a ser sospechoso de inducir a una mala comprensión del hecho científico. De este modo, asistimos desde el judaísmo al rechazo de la práctica artística por contraria a la fe, especialmente la desarrollada por las vanguardias, y a la condena del artista por obviar la prohibición tácita del recurso a la imagen. Ni la prohibición fue nunca tal ni el artista, rechazado además por sus compañeros no judíos, se arredró. Las vanguardias traerán al arte la mejor alianza entre la expresión plástica y la definición científica del saber, y los artistas judíos, herederos de todo el pasado y amamantados por su cultura milenaria, harán fructificar nuevas soluciones para mostrar esa asociación desde entonces inalterable. El arte moderno debe mucho a la particular relación del judaísmo con la ciencia a lo largo de su existencia. 


\section{BIBLIOGRAFÍA}

Abrahams, Israel, «Aristotle in Jewish Philosophy». Mind, vol. 13, núm 51 (1888), pp. 97-106.

Afonso, Luis U. (ed.), The Materials of the Image. As Matérias da Imagem. Lisboa, Cátedra de Estudos Sefarditas Alberto Benveniste da Universidade de Lisboa, 2010.

Afonso, Luis U., "New developments in the study of O livro de como se fazen as cores das tintas", en Luis U. Afonso (ed.), The Materials of the Image. As Matérias da Imagem, Lisboa, Cátedra de Estudos Sefarditas Alberto Benveniste da Universidade de Lisboa, 2010, pp. 3-27.

BArrero, A., «El aporte de Aristóteles a la Meteorología». Meteorología Colombiana, vol. 8 (2004), pp. 107-113.

Brague, Rémi, «Athens, Jerusalem, Mecca: Leo Strauss's 'Muslim' understanding of Greek Philosophy». Poetics Today, vol. 19, núm. 2 (1998), pp. 235-259.

Buber, Martín, Yo y tú. Madrid, Caparrós, 2005.

Bunge, Mario, La ciencia. Su método y su filosofía. Pamplona, Laetoli, 2013.

Campos Ribeiro, Luis, «The Children of Mercury: The image of the artist and the scientist in medieval astrological texts and iconography», en María Adelaide Miranda y Alicia MiguéLez Cavero (eds.), Portuguese Studies on Medieval Illuminated Manuscripts, Barcelona-Madrid, Fédération Internationale des Instituts d'Études Médiévales, 2014, pp. 131-144.

Collins, John J., "Cosmos and salvation: Jewish wisdom and apocalyptic in the Hellenistic Age». History of Religions, vol. 17, núm. 2 (1977), pp. 121-142.

Cruz, António J. y Luis U. Afonso, "On the date and contents of a Portuguese medieval technical book on illumination: O livro de como se fazem as cores». The Medieval History Journal, vol 11, núm. 1 (2008), pp. 1-28.

Cruz, António J., «Em busca da origem das cores de 'O Livro de Como se Fazem as Cores': sobre as fontes de um receituário portugués medieval de materiais e técnicas de pintura», en Luis U. Afonso (ed.), The Materials of the Image. As Matérias da Imagem, Lisboa, Cátedra de Estudos Sefarditas Alberto Benveniste da Universidade de Lisboa, 2010, pp. 75-85.

Evans, John H. y Michael S. Evans, «Religion and Science: Beyond the epistemological conflict narrative». Annual Review of Sociology, vol. 34 (2008), pp. 87-105.

Feldman, Louis H., "Abraham the Greek philosopher in Josephus». Transactions and Proceedings of the American Philological Association, vol. 99 (1968), pp. 143-156.

Flavio Josefo, Obras completas de Flavio Josefo. Ed. Luis Farré. Buenos Aires: Acervo Cultural, 1961.

Grant, E., The Foundations of Modern Science in the Middle Ages: Their Religious, Institutional and Intelectual Contexts. Cambridge, Cambridge University Press, 1996.

Habermas, Jürgen, Israel o Atenas. Ensayos sobre la religión, teología y racionalidad. Madrid, Ed. Trotta, 2011.

Herranz Pascual, Carmen, Los sabios del Talmud. Barcelona, Riopiedras, 1997.

Ibn Ezra, Abraham, The Beginning of Wisdom. Eds. Raphael Levy y Francisco Cantera. Londres, Oxford University Press, 1939.

Johnstone, R.L., Religion in Society: A Sociology of Religion. Upper Saddle River, NJ, Prentice Hall, 1997.

KüNG, Hans, El judaísmo. Pasado, presente y futuro. Madrid, Ed. Trotta, 1993. 
Langermann, Y. Tzvi, «Science in the Jewish communities», en D. Lindberg y M. Shank (eds.), The Cambridge History of Science, Cambridge, Cambridge University Press, 2013, pp. 168-189.

Langermann, Y. Tzvi, The Jews and the Sciences in the Middle Ages. Variorum Collected Studies Series. Brookfield, VT, Ashgate Publishing Company, 1999.

Lewy, Hans, «Aristotle and the Jewish Sage According to Clearchus of Soli». The Harvard Theological Review, vol. 31, núm. 3 (1938), pp. 205-235.

Lomba Fuentes, Joaquín (ed.), Ibn Gabirol, Ibn Paqûda, Pedro Alfonso. Dichos y narraciones de tres sabios judios. Zaragoza, Mira Editores, 1997.

Lomba Fuentes, Joaquín, El Ebro: Puente de Europa. Pensamiento musulmán y judío. Zaragoza, Mira Editores, 2002.

Miranda, María Adelaide y Alicia Miguélez Cavero (eds.), Portuguese Studies on Medieval Illuminated Manuscripts. Barcelona-Madrid, Fédération Internationale des Instituts d'Études Médiévales, 2014.

Miranda, María Adelaide y María J. Melo, «Secrets et découvertes en couleur dans le manuscrit enluminés», en María Adelaide Miranda y Alicia Miguélez Cavero (eds.), Portuguese Studies on Medieval Illuminated Manuscripts, Barcelona-Madrid, Fédération Internationale des Instituts d'Études Médiévales, 2014, pp. 1-29.

Murphy, Roland E., «Hebrew Wisdom». Journal of the American Oriental Society, vol. 101, núm. 1 (1981), pp. 21-34.

Newman, William R., «What have we learned from the recent historiography of Alchemy?». Isis, vol. 102, núm. 2 (2011), pp. 313-321.

Orfali, Moisés, «Los responsa rabínicos y la vida interna en las aljamas aragonesas». Aragón Sefarad, vol. 1 (2005), pp. 161-175.

PataI, Raphael, The Jewish Alchemists: A History and Source Book. Princeton, NJ, Princeton University Press, 1994.

Priest, John F., «Where is wisdom to be placed?». Journal of Bible and Religion, vol. 31, núm. 4 (1963), pp. 275-282.

RoIz, Javier, A Vigilant Society: Jewish Thought and the State in Medieval Spain. Albany, State University of New York, 2013.

Romano, David, La ciencia hispanojudia. Madrid, Mapfre, 1992.

Rosenberg, Salom, El bien y el mal en el pensamiento judio. Barcelona, Riopiedras, 1996.

Rотн, Cecil, The Jews in the Renaissance. Filadelfia, The Jewish Publication Society of America, 1977.

SABRA, A., «The appropriation and subsequent naturalization of Greek science in medieval Islam: A Preliminary Statement». History of Science, vol. 25 (1987), pp. 223-243.

SACCHI, Paolo, Historia del Judaísmo en la época del Segundo Templo. Madrid, Ed. Trotta, 2004.

SAmsó, Julio, Las Ciencias de los antiguos en Al-Andalus. Madrid, Mapfre, 1992.

Schiaparelli, G., Scritti sulla Storia della Astronomia antica, vol. i. Bolonia, Associazione Culturale Mimesis, 1925.

Sed Rajna, Gabrielle et alt., L'art juif. París, Citadelles \& Mazenod, 1995.

SELA, Shlomo, «La creación del mundo supralunar según Abraham ibn Ezra: un estudio comparativo de sus dos comentarios a Génesis 1, 14». Sefarad, vol. 63 (2003), pp. 147-181. 
Shestov, Leo, Afiny i Ierusalim. París, YMCA Press, 1951.

Sirat, Colette, A History of Jewish Philosophy in the Middle Ages. Cambridge, Cambridge University Press, 1990.

Strauss, Leo, The Rebirth of Classical Political Rationalism. An Introduction to the Thought of Leo Strauss. Essays and Lectures by Leo Strauss, Selected and Introduced by Thomas L. Pangle. Chicago, University of Chicago Press, 1989.

Whitfield, Stephen J., «The Jew as Wisdom Figure». Modern Judaism, vol. 13, núm. 1 (1993), pp. 1-24.

Wirth, J., L'image à l'époque romane. París, Cerf, 1999. 
